\title{
Strawberry Anthracnose: Histopathology of Colletotrichum acutatum and C. fragariae
}

\author{
Kenneth J. Curry, Maritza Abril, Jana B. Avant, and Barbara J. Smith
}

First, second, and third authors: University of Southern Mississippi, Hattiesburg 39406; and fourth author: U.S. Department of Agriculture, Agricultural Research Service, Small Fruit Research Station, P.O. Box 287, Poplarville, MS 39470. Accepted for publication 23 May 2002.

\begin{abstract}
Curry, K. J., Abril, M., Avant, J. B., and Smith, B. J. 2002. Strawberry anthracnose: Histopathology of Colletotrichum acutatum and $C$. fragariae. Phytopathology 92:1055-1063.

Ontogeny of the invasion process by Colletotrichum acutatum and $C$. fragariae was studied on petioles and stolons of the strawberry cultivar Chandler using light and electron microscopy. The invasion of host tissue by each fungal species was similar; however, each invasion event occurred more rapidly with $C$. fragariae than with $C$. acutatum. Following

began invasion with a brief biotrophic phase before entering an extended necrotrophic phase. Acervuli formed once the cortical tissue had been moderately disrupted and began with the development of a stroma just beneath the outer periclinal epidermal walls. Acervuli erupted through the cuticle and released conidia. Invasion of the vascular tissue typically occurred after acervulus maturation and remained minimal. Chitin distribution in walls of $C$. fragariae was visualized with gold-labeled wheat germ agglutinin. The outer layer of bilayered walls of conidia, germ tubes, and appressoria contained less chitin than unilayered hyphae in planta.
\end{abstract} cuticular penetration via an appressorium, subsequent steps of invasion involved hyphal growth within the cuticle and within the cell walls of epidermal, subepidermal, and subtending cells. Both species of fungi
Additional keywords: colloidal gold, hemibiotrophy, host-pathogen interactions, lectin, ultrastructure.
Anthracnose diseases of strawberry (Fragaria $\times$ ananassa Duch.) are caused by the fungal pathogens Colletotrichum acutatum Simmonds, C. fragariae Brooks, and C. gloeosporioides (Penz.) Penz. and Sacc. (teleomorph Glomerella cingulata (Stonem.) Spauld. \& Schrenk) (8,21-23,26). All three species incite diseases, which cannot be distinguished in the field by symptoms alone. Petiole and stolon lesions occur on plants grown worldwide, but may go undetected in cool, dry areas where they cause little injury to the plants. $C$. fragariae is most often associated with anthracnose crown rot of strawberries grown in hot, humid areas such as the southeastern United States. Its host range is limited to strawberries and a few weeds (22). C. acutatum is the primary causal agent of anthracnose fruit rot, has a broader geographic and host range than $C$. fragariae $(8,10,22)$, and is increasing in importance as a cause of petiole, stolon, crown, and root infections (7).

A large number of light and electron microscopic studies describing plant interactions with Colletotrichum species have been published, but we have not found studies on the ultrastructure of the $C$. acutatum- and $C$. fragariae-strawberry systems. A consideration of the detailed natures of biotrophy, necrotrophy, and hemibiotrophy is necessary in understanding the invasion mechanisms of $C$. acutatum and C. fragariae. Biotrophy is the condition in which the fungus maintains its host cells alive while removing nutrients from them $(9,16)$. Necrotrophy is the condition in which the fungus approaches living host cells and kills them before entering their lumina $(9,12,16,28)$. Hemibiotrophy is a condition in which the fungus initially enters a biotrophic phase and then switches to a necrotrophic phase (9). The initial penetration and invasion processes of a plant host by a fungal pathogen in the

Corresponding author: B. J. Smith; E-mail address: BarbaraSmith@ars.usda.gov

Publication no. P-2002-0726-01R

This article is in the public domain and not copyrightable. It may be freely reprinted with customary crediting of the source. The American Phytopathological Society, 2002. absence of a significant plant resistant response ensure successful colonization of host tissue and subsequent necrotrophic activities. Bailey et al. (1) described two major invasion strategies, intracellular hemibiotrophic invasion and subcuticular intramural invasion. Early stages of invasion for both strategies include conidial adhesion to the host surface, germination of conidia, production of germ tubes, and penetration of the host cuticle via appressoria. Subcuticular intramural pathogens grow within the cuticle and within the cell walls of epidermal, subepidermal, and subtending cells killing host cells prior to entering them (necrotrophic phase). Intracellular hemibiotrophic pathogens invade living cells for a short time, maintaining them apparently for nutritional advantage, and then convert to a necrotrophic phase.

The role of chitin both as a host defense elicitor and as a target for plant chitinases is well documented $(3,18,20)$. Several fungi are known to modify or mask chitin in structures involved in early penetration presumably to avoid detection by the host or to avoid the effects of host chitinases. A lectin probe, gold-labeled wheat germ agglutinin, was chosen to study the distribution of chitin in the walls of $C$. fragariae during the initial infection of the strawberry host. The purpose of this study was to document the invasion strategies of $C$. acutatum and $C$. fragariae in strawberry with respect to strategies previously described by Bailey et al. (1), and to examine the degree to which chitin was present in various fungal infective structures.

\section{MATERIALS AND METHODS}

Propagation of strawberry plants. Strawberry plants (cv. Chandler) were planted in $10-\times 10-\mathrm{cm}$ plastic pots containing a $1: 1$ (vol/vol) mixture of Jiffy-Mix (JPA, West Chicago, IL) and pasteurized sand and grown for at least 6 weeks before inoculation in a greenhouse maintained at $30^{\circ} \mathrm{C}$ day $/ 18^{\circ} \mathrm{C}$ night $\pm 6^{\circ} \mathrm{C}$ with a $16-\mathrm{h}$ photoperiod. Older leaves, runners, and flowers were removed 1 to 7 days before inoculation, and three or four young leaves remained on each plant at inoculation. 
TABLE 1. Time from inoculation of strawberry (Fragaria $\times$ ananassa) cv. Chandler with two Colletotrichum spp. to first observation of infection events

\begin{tabular}{|c|c|c|c|c|}
\hline \multirow[b]{2}{*}{ Event } & \multicolumn{2}{|c|}{$\begin{array}{l}\text { Colletotrichum } \\
\text { acutatum }\end{array}$} & \multicolumn{2}{|c|}{$\begin{array}{c}\text { Colletotrichum } \\
\text { fragariae }\end{array}$} \\
\hline & Petiole $^{\mathrm{a}}$ & Stolon $^{\mathrm{b}}$ & Petiole $^{\mathrm{a}}$ & Stolon ${ }^{\mathrm{b}}$ \\
\hline Visible lesion & 4 days & 3 days & 3 days & 2 days \\
\hline Girdling lesion & 5 days & 5 days & 4 days & 3 days \\
\hline Acervulus formation & 5 days & 5 days & 4 days & 3 days \\
\hline Hyphae visible in cortex & 4 days & 3 days & 3 days & 2 days \\
\hline Cortical cell collapse & 5 days & 4 days & 4 days & 3 days \\
\hline Epidermal cell collapse & $\begin{array}{c}\text { Did not } \\
\text { occur }\end{array}$ & $\begin{array}{c}\text { Did not } \\
\text { occur }\end{array}$ & $\begin{array}{l}\text { Did not } \\
\text { occur }\end{array}$ & $\begin{array}{c}\text { Did not } \\
\text { occur }\end{array}$ \\
\hline
\end{tabular}

a Based on 25 or more observations.

b Based on 10 or more observations.
Inoculation of plants. Isolates of $C$. acutatum Goff and $C$. fragariae CF-63 and CF-75 (26) were maintained on silica gel at USDA-ARS in Poplarville, MS. These isolates were grown on potato dextrose agar (PDA) for 14 to 21 days at $25^{\circ} \mathrm{C}$ under fluorescent light at $14 / 10 \mathrm{~h}$ of light/dark intervals. The cultures were located approximately $18 \mathrm{~cm}$ beneath four fluorescent tubes (Sylvania Super Saver Lite White, $34 \mathrm{~W}, 16.7 \mu \mathrm{mol} \cdot \mathrm{m}^{2} \cdot \mathrm{s}^{-1}$; OSRAM Sylvania, Danvers, MA). Conidial suspensions used for inoculations were prepared by flooding each PDA culture plate with sterile deionized water and gently scraping the agar surface with a glass rod to remove conidia. The resulting conidial suspension was filtered through cheesecloth and a final conidial suspension of $1.5 \times 10^{6}$ conidia per $\mathrm{ml}$ was used to inoculate strawberry plants.

Attached petioles and stolons were inoculated by misting to the point of runoff or by spot inoculation. Plants were incubated in a
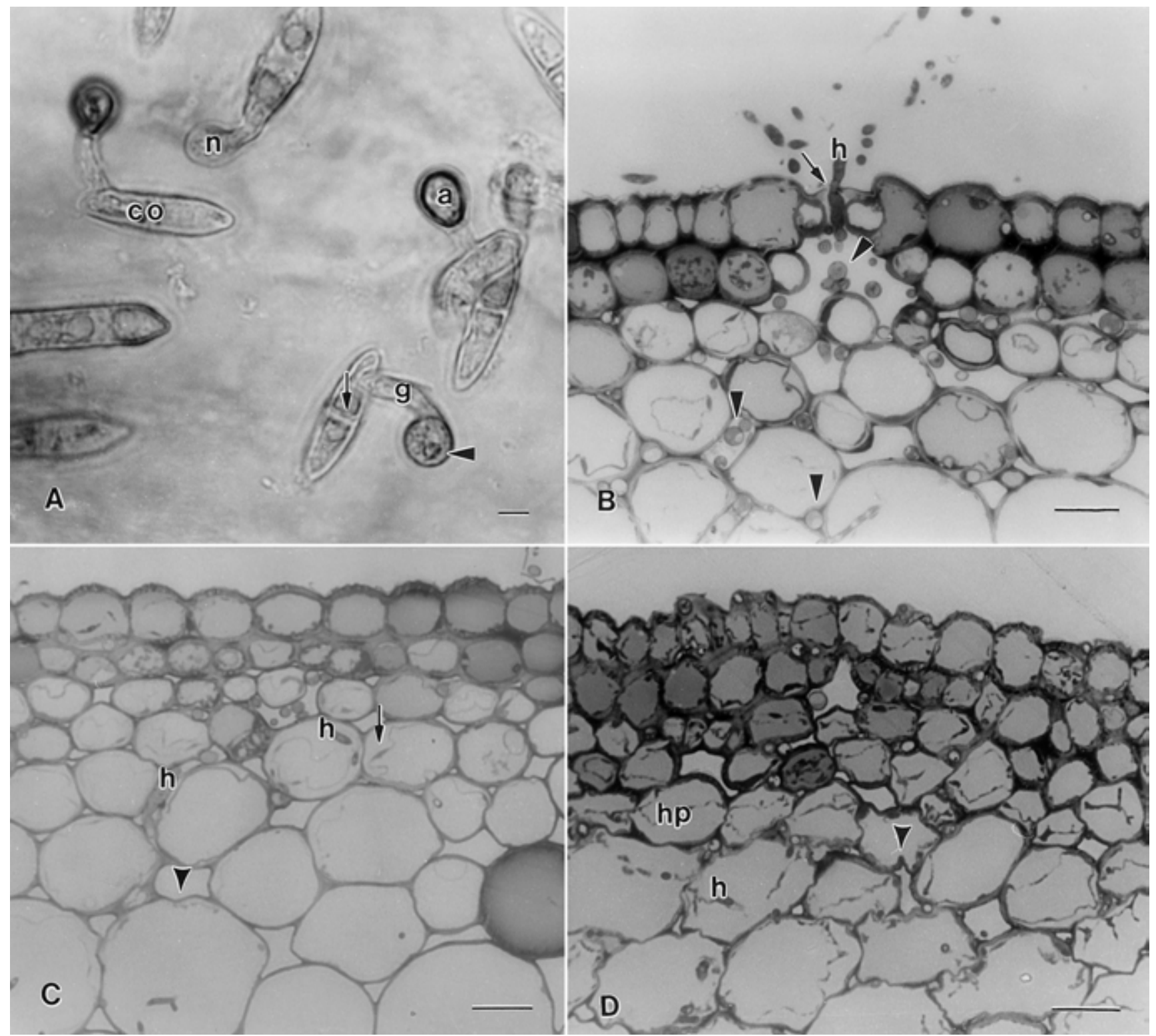

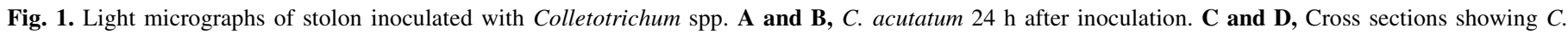

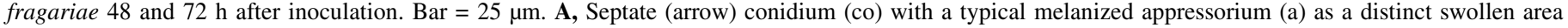

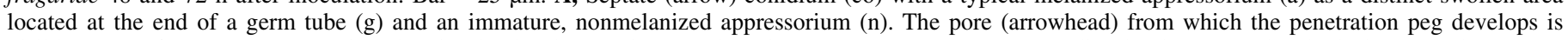

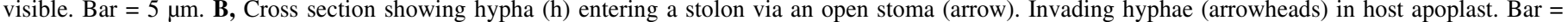

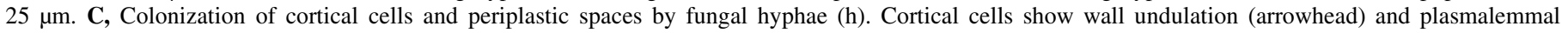

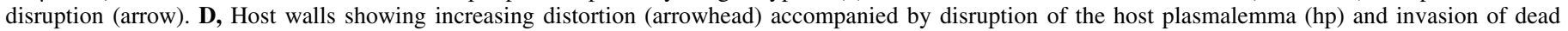
cells by fungal hyphae (h). 
sealed 10 -gallon tank at $100 \%$ relative humidity for $24 \mathrm{~h}$ and then at reduced relative humidity by removing half of the plastic tank cover for the remainder of the incubation time $(25,26)$. Plants inoculated with $C$. acutatum were incubated at $28^{\circ} \mathrm{C}$; those inoculated with $C$. fragariae were incubated at $32^{\circ} \mathrm{C}$. Following inoculation, petioles and stolons were examined microscopically at 8- to 10 -h intervals for $96 \mathrm{~h}$ to document the morphology and time required for germ tube development, appressorial formation, penetration of the epidermis, subsequent invasion of tissue, development of disease symptoms, and acervulus production.

Tissue processing. Symptomatic tissue was fixed for $2 \mathrm{~h}$ in $0.1 \mathrm{M}$ sodium cacodylate buffer ( $\mathrm{pH} 7.0$ ), 2.0\% formaldehyde, and $2.5 \%$ glutaraldehyde. Tissue was rinsed with distilled water and postfixed $45 \mathrm{~min}$ in cacodylate buffered (pH 7.0) $1 \%$ osmium tetroxide. Tissue was dehydrated with an ethanol series $(50,70$, 85,95 , and $100 \%$ ) followed by propylene oxide. Tissue was then infiltrated in 50/50\% by volume ERL 4206 resin (Spurr's)/ propylene oxide for $4 \mathrm{~h}$ on a rotator, followed by 75/25\% by volume resin/propylene oxide change overnight on a rotator. Tissue was infiltrated with two changes of $100 \%$ resin during an 8 -h period and cured at $70^{\circ} \mathrm{C}$ for 24 to $36 \mathrm{~h}$. ERL 4206 resin contained nonenyl succinic anhydride (26 g), vinyl cyclohexene dioxide (10 g), diglycidyl ether (6 g), and dimethylaminoethanol $(0.2 \mathrm{~g})$.

Slides with semithin sections $(\approx 1 \mu \mathrm{m})$ were placed on a hotplate at $55^{\circ} \mathrm{C}$, stained for 1 to $2 \mathrm{~min}$ with $0.1 \%$ aqueous toluidine blue$\mathrm{O}$, and examined with a light microscope. Ultrathin sections $(\approx 100 \mathrm{~nm}$ ) were taken with a Porter-Blum MT-2B microtome (Ivan Sorvall, Inc., Newton, CT) and a diamond knife (Diatome-U.S., Fort Washington, PA) and collected on 200-mesh copper grids. Grids were stained with lead citrate (19) and 2\% aqueous uranyl acetate. Sections were viewed using a Zeiss EM 10-C transmission electron microscope (Carl Zeiss, Inc., Thornwood, NY).

We developed a procedure to aid in the location of appressoria on fixed, embedded material. Slivers of epidermal tissue on which appressoria had been seen with a compound microscope were flat embedded in 2 to $3 \mathrm{~mm}$ of resin and cured at $70^{\circ} \mathrm{C}$ for 20 to $24 \mathrm{~h}$. Appressoria on the host tissue were identified through the thin plastic with a compound microscope, and hand sections containing appressoria were obtained. Those hand sections were then remounted with Duco cement (Devcon, Danvers, MA) on prefaced stubs (created by curing Spurr's plastic in polyethylene Beem
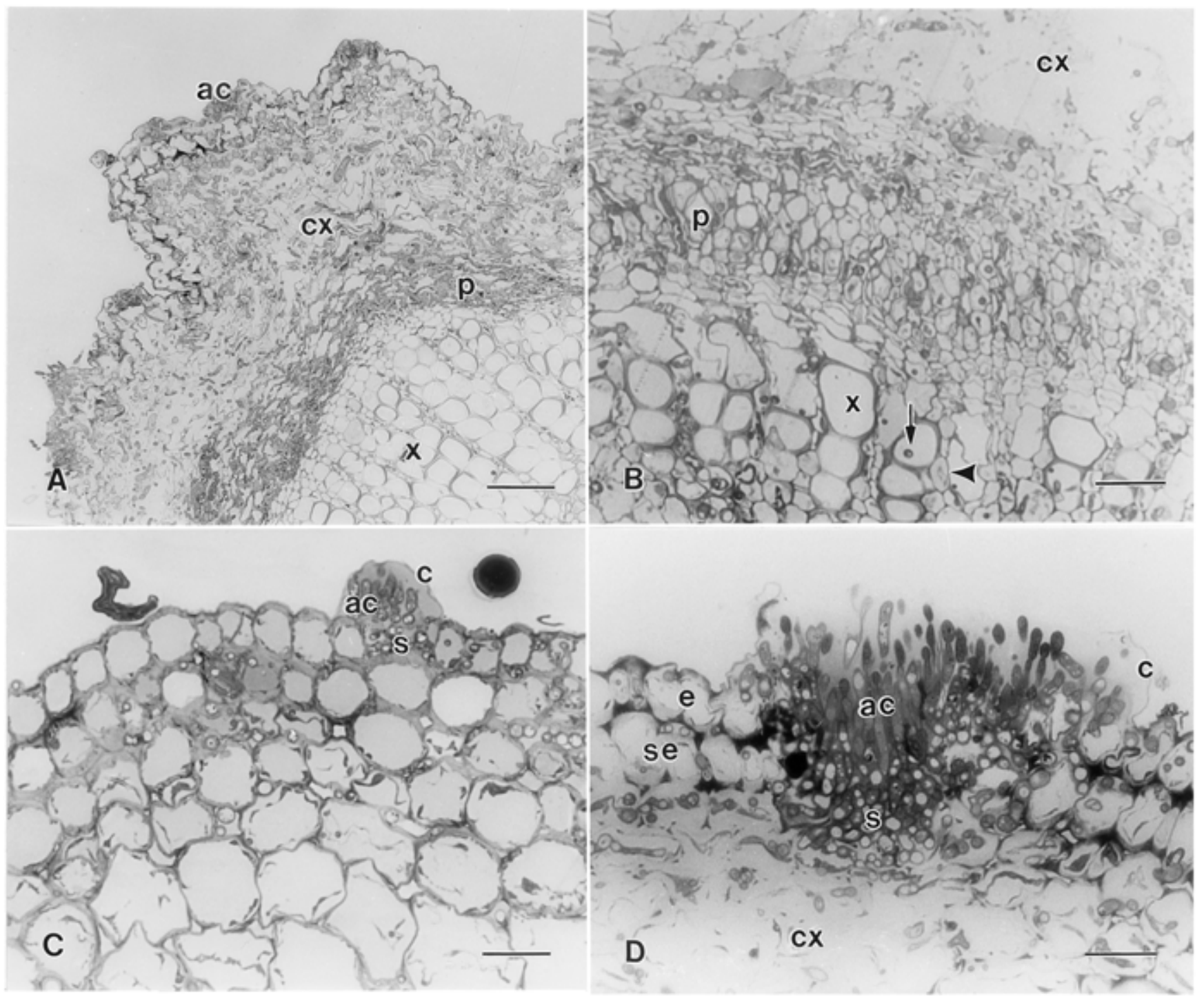

Fig. 2. Light micrographs $72 \mathrm{~h}$ after inoculation with Colletotrichum spp. A, Petiole inoculated with C. acutatum. Bar $=50 \mu \mathrm{m}$. B, C, and D, Stolon inoculated with $C$. fragariae. Bar $=25 \mu \mathrm{m}$. A, Advanced stage of invasion showing disrupted cortex and mature acervulus on intact epidermal and subepidermal layers. Vascular tissue (phloem and xylem) remains intact at this point. B, Hyphae invading parenchyma cells (arrowhead) and vessel members (arrow). C, Expansion of the host cuticle as the acervulus enlarges. D, The mature acervulus and stroma usually occupy the epidermal (e) and subepidermal (se) host layers while the cortex experiences massive destruction. $\mathrm{ac}=$ acervulus; $\mathrm{s}=$ stroma; $\mathrm{c}=$ cuticle; $\mathrm{cx}=$ cortex; $\mathrm{hw}=$ host wall; $\mathrm{p}=\mathrm{phloem} ; \mathrm{x}=\mathrm{xylem}$. 


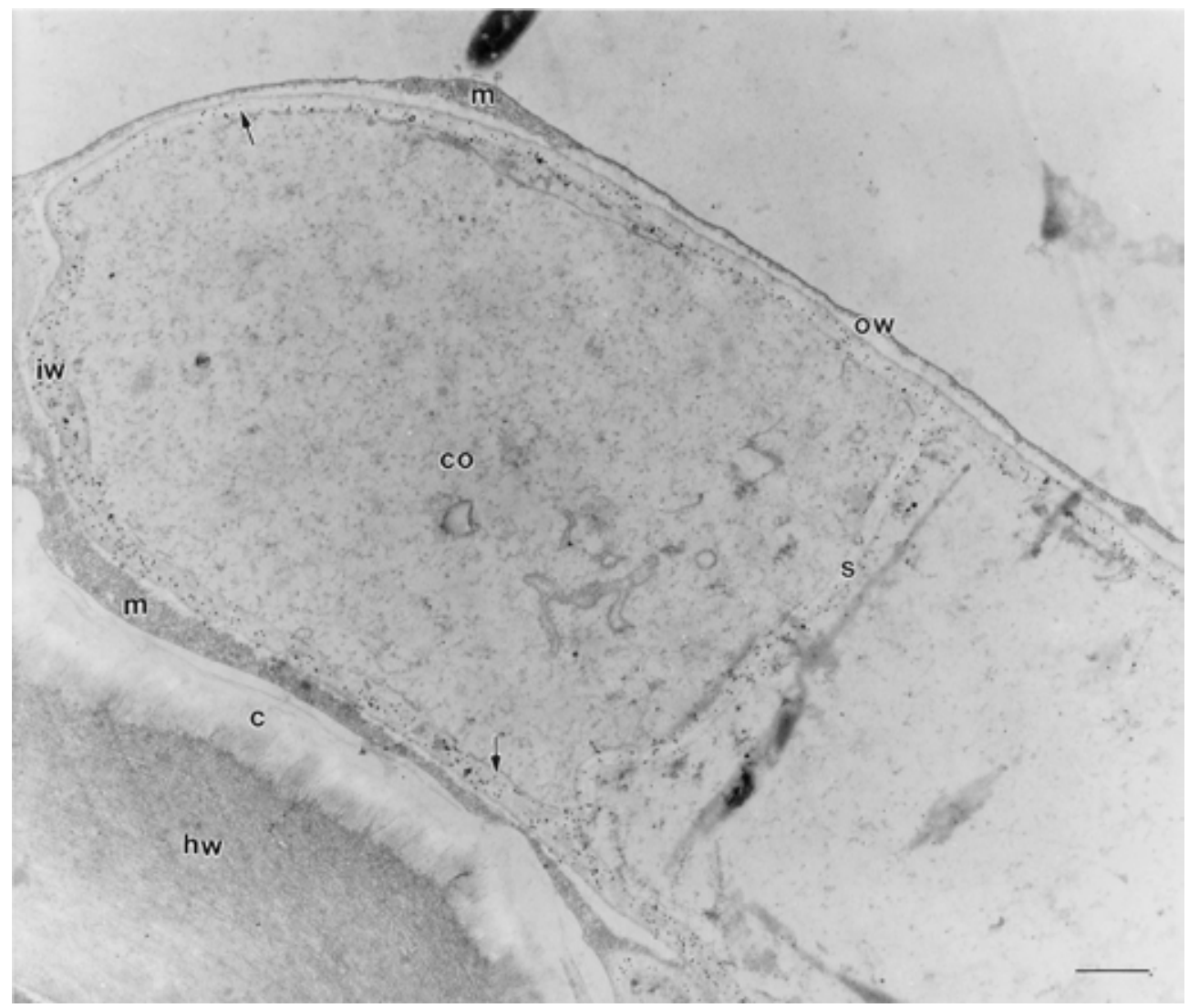

Fig. 3. Electron micrograph of a germinated conidium (co) of Colletotrichum fragariae showing the gold probe labeling chitin on the inner wall (arrows) and the septum (s). The probe is absent from the outer wall and the matrix (m). $\mathrm{c}=$ cuticle; hw $=$ host wall; iw $=$ inner wall; ow $=$ outer wall. Bar $=50 \mathrm{~nm}$.

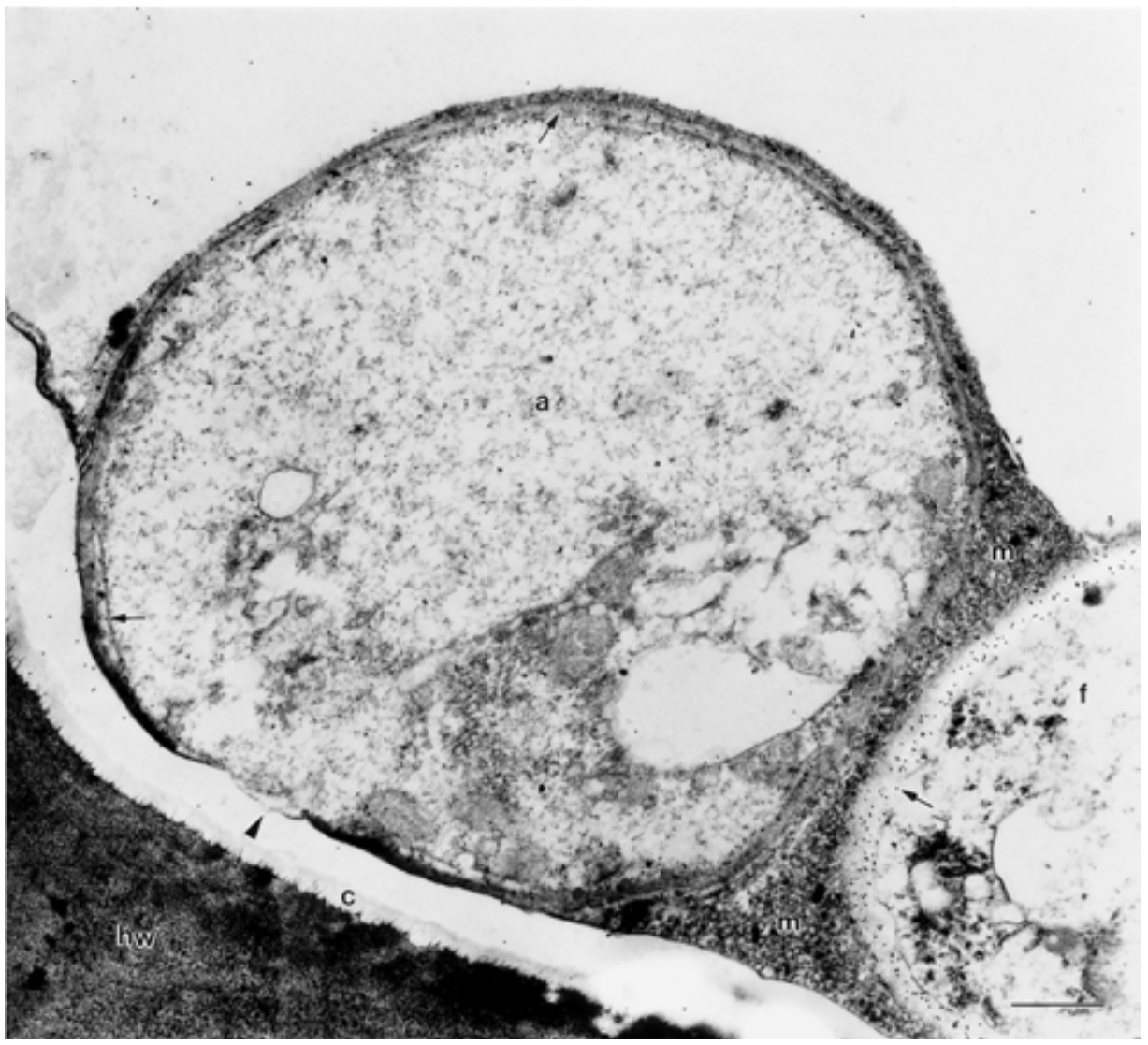

Fig. 4. Electron micrograph of an appressorium (a) of Colletotrichum fragariae separated from an adjacent fungal cell (f) by a matrix (m). The probe labeled the inner walls (arrows) and not the outer walls or matrix. The basal pore (arrowhead) is located on the basal portion of the appressorium and delimited by a membrane. $\mathrm{c}=$ cuticle; $\mathrm{hw}=$ host wall. $\mathrm{Bar}=50 \mathrm{~nm}$. 
capsules size " 00 " and trimmed with a $1 \times 1 \mathrm{~mm}$ face) for ultrathin sectioning.

Application of wheat germ agglutinin lectin probe for chitin. The application of the wheat germ agglutinin probe (WGA; L-9640, Sigma, St. Louis) was modified from Benhamou (2). The ultrathin sections on 200-mesh nickel grids were floated on a drop of $0.01 \mathrm{M}$ phosphate buffered saline (PBS; $40 \mathrm{ml}$ of $0.02 \mathrm{M}$ potassium hydroxide, $50 \mathrm{ml}$ of $0.02 \mathrm{M}$ potassium di-

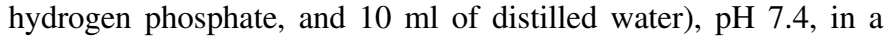
moist chamber for $1 \mathrm{~h}$. Grids were subsequently incubated for $2 \mathrm{~h}$ in a moist chamber in $15 \mu \mathrm{l}$ of lectin-gold complex at the concentration supplied by the manufacturer of $1.4 \times 10^{13}$ particles per $\mathrm{ml}$. The probe was lectin from Triticum vulgaris conjugated to $10 \mathrm{~nm}$ colloidal gold particles. Each grid was then washed by dipping repeatedly and gently for $10 \mathrm{~s}$ into PBS. Grids were air dried and then stained with lead citrate and uranyl acetate as described above.

Controls. Four-day-old cultures of $C$. fragariae grown on PDA as described above were overlaid by a thin layer of $2 \%$ agar to hold the mycelium together. Pieces of the culture were cut into plugs $3 \times 3 \mathrm{~mm}$, fixed and processed for ultrathin sectioning, and probed with gold-labeled lectin as previously described.
The specificity of the WGA lectin binding was determined by the following tests used by Benhamou (2). These controls were run simultaneously with the application of the normal probe on symptomatic tissue. (1) The gold-labeled lectin was first preadsorbed with poly-(1-4)- $\beta-N$-acetyl-D-glucosamine purified from crab shells (C-9752, Sigma, St. Louis) at a concentration of $1 \mathrm{mg}$ per $2 \mathrm{ml}$ of probe for $1 \mathrm{~h}$ and then applied as described above to sections containing fungi from a strawberry petiole lesion $1 \mathrm{~mm}$ or larger. (2) The ultrathin sections were floated on a drop of PBS for $1 \mathrm{~h}$ and probed with wheat germ agglutinin without a gold label for $1 \mathrm{~h}$. The remainder of the probe application was as described above.

\section{RESULTS}

Light microscopy. The ontogeny of the infection processes of $C$. acutatum and $C$. fragariae on inoculated plants were similar (Table 1) at the light or electron microscopic levels. Lesions most commonly developed on stolon tips and the upper portion of the youngest petiole with fully expanded leaflets. Lesions were first observed 2 days after inoculation as lenticular brown spots that developed into the dark, sunken, and leathery

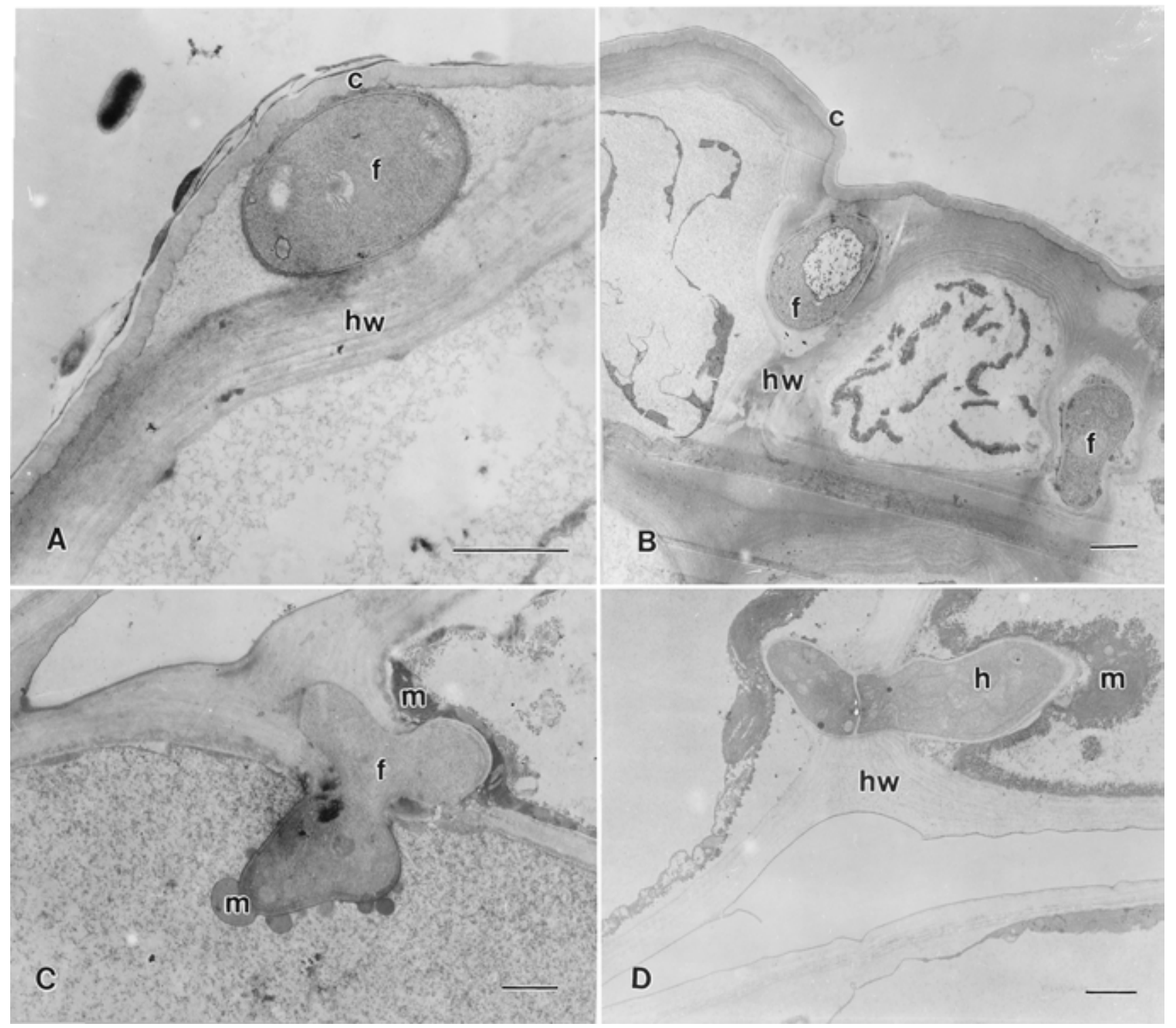

Fig. 5. Electron micrographs of strawberry tissue inoculated with Colletotrichum spp. A and B, Early stages of invasion of petiole $116 \mathrm{~h}$ after inoculation with C. acutatum. C and D, Fungal cells of $C$. fragariae penetrating living host cells of stolon. A, Fungal cell under the host cuticle. B, Fungal cell in anticlinal host wall. $\mathbf{C}, 116 \mathrm{~h}$ after inoculation. $\mathbf{D}, 48 \mathrm{~h}$ after inoculation. $\mathrm{c}=$ cuticle; $\mathrm{f}=$ fungal cell; $\mathrm{h}=$ hypha; $\mathrm{hw}=$ host wall; $\mathrm{m}=$ matrix. $\mathrm{Bar}=2 \mu \mathrm{m}$. 
lesions typical of anthracnose that eventually girdled the stolon or petiole.

Spore germination began as early as $16 \mathrm{~h}$ after inoculation, with the germ tubes originating from either end of a conidium and occasionally from both ends. Germ tubes generally spanned one plant cell length or less, but occasionally grew across several cells. Appressorial formation began as early as $20 \mathrm{~h}$ after inoculation. Development of an appressorium began as a swelling of the germ tube tip. Appressorial development could occur on such a short germ tube as to appear sessile. Appressoria were initially unmelanized, but by $24 \mathrm{~h}$ they were fully pigmented (Fig. 1A). Small circular areas on the basal sides of appressoria, seen by focusing through an appressorium with the light microscope, were interpreted to be pores from which the penetration pegs developed (Fig. 1A). The typical mature appressorium for either species was globose and approximately 3 to $5 \mu \mathrm{m}$ in diameter. Appressoria frequently developed over anticlinal host walls, but occasionally, were found over periclinal walls or near stomata. Appressoria and their basal pores were found on the surface of both healthy and diseased plant tissue.

The first signs of host cell distress appeared when the cell wall contour became distorted, and the plasmalemma pulled away from the cell wall (Fig. 1B to D). Hyphae during early stages of lesion formation were less abundant in epidermal and subepidermal cells than in cortical cells. A gradual increase of fungal hyphae in the host cuticle, epidermis, and subepidermis was observed with hyphae restricted to the apoplast in early stages of invasion and then invading dead cells (Fig. 1B to D). As the infection progressed, cell walls became increasingly distorted (Fig. 1D). In contrast to disrupted cortical cell walls, epidermal and subepidermal walls remained intact even though hyphae penetrated their walls (Fig. 2A). Invasion of the vascular tissue and acervulus

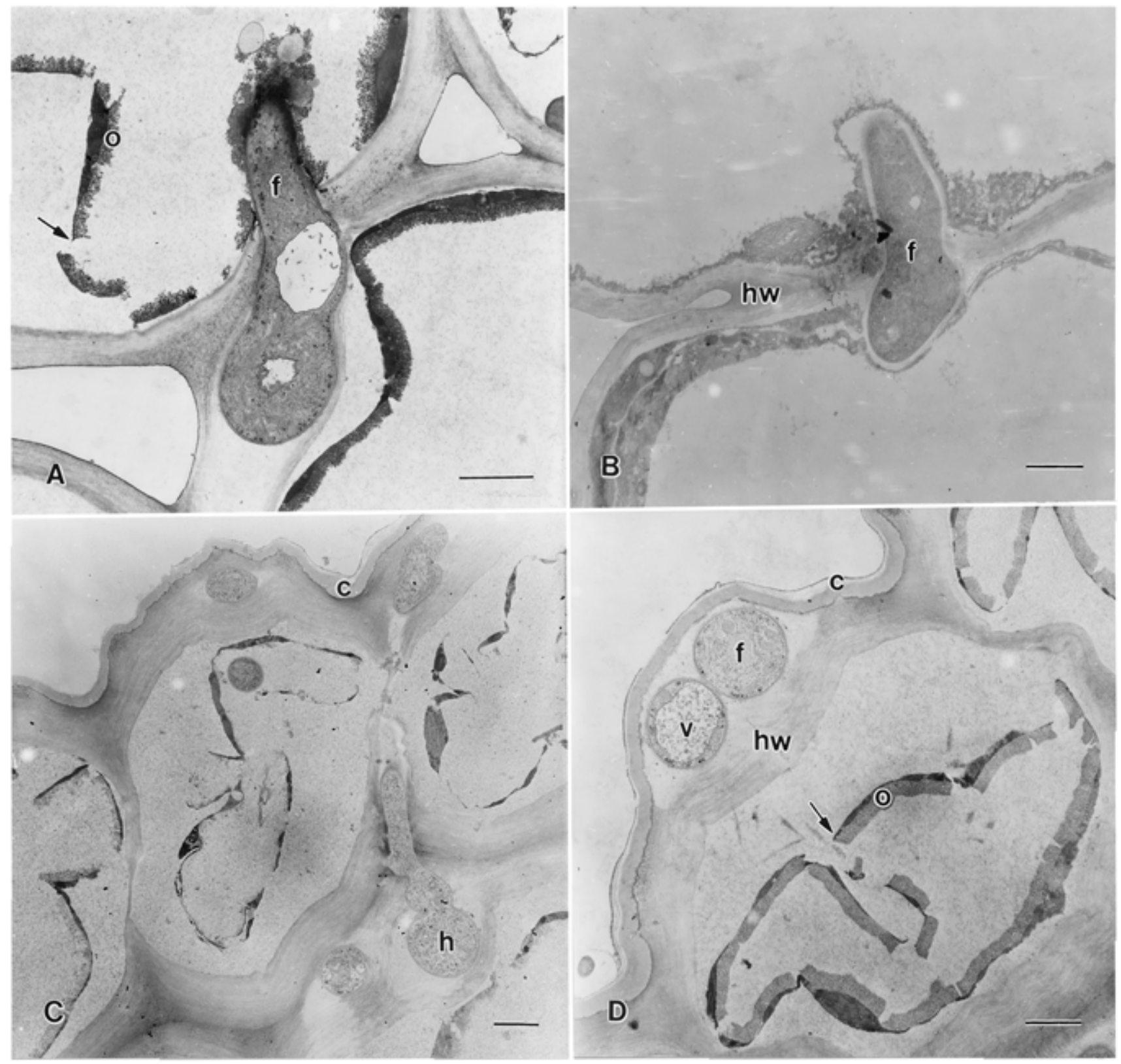

Fig. 6. Electron micrographs showing later stages of invasion. A, Stolon $72 \mathrm{~h}$ after inoculation with Colletotrichum fragariae. B, Petiole $116 \mathrm{~h}$ after inoculation with C. acutatum. A and B, Penetration of dead host cells. Some host cells were characterized by electron dense osmiophilic material associated with the tonoplast (A), while others were not (B). C and D, Early development of a stroma in stolon $116 \mathrm{~h}$ after inoculation with $C$. fragariae. C, Hypha (h) growing from the subepidermis to the epidermal layer. D, Initial stromatic fungal cells located between the cuticle and the host wall of the epidermal layer. Note the increasing degree of vacuolation $(\mathrm{v})$ of fungal cells, the disruption of the tonoplast, and the presence of abundant osmiophilic material. $\mathrm{c}=$ cuticle; $\mathrm{e}=$ epidermal layer; $\mathrm{f}=$ fungal cell; $\mathrm{hw}=$ host wall; $\mathrm{o}=$ osmiophilic material; arrow $=$ tonoplast. $\mathrm{Bar}=2 \mu \mathrm{m}$. 
formation occurred concurrently (Fig. 2A and B). The fungus was seen in vessel elements (Fig. 2B) during this last phase of the invasion process.

Acervulus formation began with the development of a stroma within the cuticle of epidermal cells. The cuticle expanded considerably to accommodate the growing acervulus (Fig. 2C). The maturing acervulus broke through the cuticle and eventually produced conidia (Fig. 2D). The acervulus expanded radially with the stroma also extending from the epidermis to the subepidermis. Acervuli were produced over a disrupted cortex, or in extreme cases, over a completely disintegrated cortex (Fig. 2D). In either case, the epidermal and some of the subepidermal tissue remained intact.

The invasion of host tissue by $C$. fragariae and $C$. acutatum was similar. However, each invasion event occurred more rapidly with $C$. fragariae than with $C$. acutatum (Table 1). Lesions were visible on petioles 3 days after inoculation with $C$. fragariae, but were not visible until 4 days after inoculation with $C$. acutatum. A similar delay in invasion events was observed between petiole and stolen tissues following inoculation of either species. Most events were observed a day sooner on the stolons than on the petioles within species.

Electron microscopy. The conidial and germ tube walls comprised two layers, with the outer layer being thinner and more electron dense than the inner layer. Only the inner conidial layer was labeled by the WGA probe (Fig. 3). Upon germination, a septum was laid down bisecting the conidium (Fig. 3), and one also developed between the conidium and the germ tube. The WGA probe was observed on the inner wall layers of the germ tube and its septa. A few vesicles were present in the germ tube after maturation of the appressorium, although no distinct orga- nelles were seen. The probe was not found in the cytoplasm of germ tubes or appressoria.

Appressoria were sometimes covered by an extracellular matrix that was somewhat amorphous with dispersed fibrillar material. The appressorial matrix was not labeled by the WGA probe (Fig. 4). The upper wall of the appressorium appeared to have two distinct layers, with the probe being restricted to the inner layer (Fig. 4). The two layers became gradually indistinct as they approached the basal side of the appressorium. The appressorial pore was defined by the appressorial wall tapering toward a central area on the basal side. The pore was usually occluded by a membrane (Fig. 4). No evidence of labeling was found on either the host cytoplasm or walls (Fig. 4).

Some hyphae invaded the cuticle (Fig. 5A), outer epidermal wall, and anticlinal walls of the epidermis (Fig. 5B). Some hyphae initially penetrated what appeared to be living host cells (Fig. 5C and D). The host plasmalemma invaginated to accommodate hyphal penetration. The interface of the host membrane and hyphal wall was frequently associated with a particular arrangement of electron dense material (Fig. 5C and D). Several degrees of disturbance and relaxation of the microfibrillar components of cell walls were observed during penetration of host cells including early penetration events (Fig. 5A). Death of fungal cells was a rare occurrence.

Several dying host cells exhibited an amorphous, osmiophilic material around the inside portion of the tonoplast (Fig. 6A, C, and D); others did not (Fig. 6B). Some cortical fungal hyphae appeared to be growing back to the epidermis in the stage prior to acervulus formation (Fig. 6C). Acervulus formation involved the development of a subcuticular stroma within and beneath the outer host epidermal cell walls (Fig. 6D). A gradual vacuolation de-

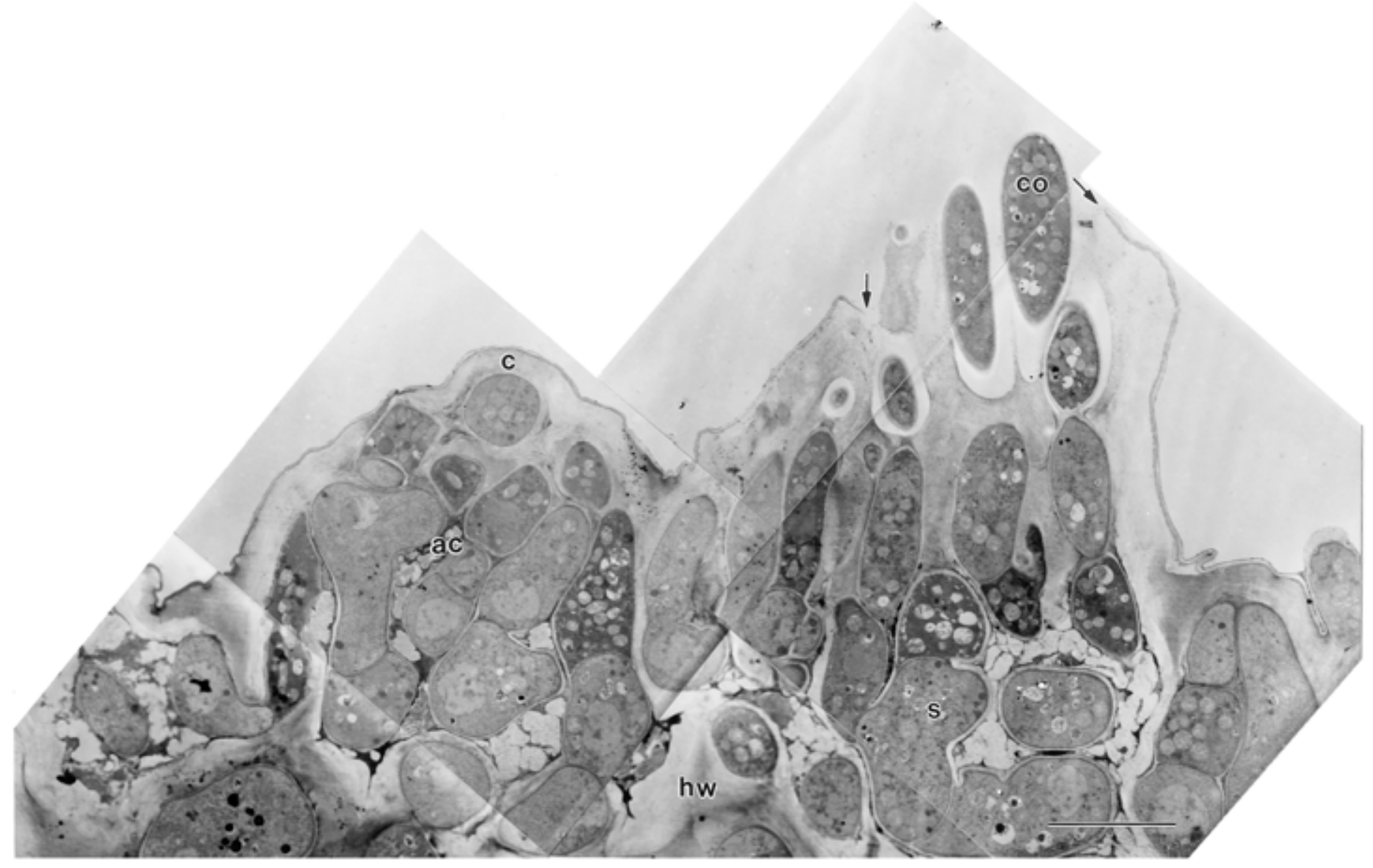

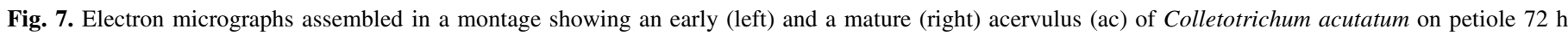

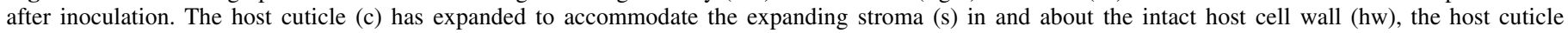
(arrows) has ruptured, and early development of conidia (co) has commenced. Bar $=5 \mu \mathrm{m}$. 
veloped in stromatic cells (Fig. 6D). The stroma continued to develop into the epidermal and adjacent subepidermal cells, finally rupturing the cuticle (Fig. 7). Late development of the acervulus included the extension of the host cuticle to accommodate the expanding stroma, the rupture of the cuticle, and early development of conidia (Fig. 7). C. acutatum and C. fragariae had a pulvinate type of acervulus (27).

Controls. There were no apparent variations in the labeling of walls of fungi grown on PDA when compared to both young and older hyphae from lesions in planta. The WGA probe was evenly distributed on the unilayered walls. Septa were labeled with the same intensity as the outer walls.

Labeling was diminished as expected when the probe was preadsorbed with chitin (control 1). Labeling was diminished as expected when the sections were incubated with lectin before applying the lectin-gold complex (control 2).

\section{DISCUSSION}

C. acutatum and $C$. fragariae underwent a very brief biotrophic phase (less than $12 \mathrm{~h}$ ) before entering their extended necrotrophic phase. Representatives of both species of fungi were observed entering living host cells and developing a matrix comparable to that described in reported biotrophic systems $(4,11,13,15)$, but they killed the host cells within a few hours. Previous descriptions for other Colletotrichum species cite biotrophy at a minimum of "less than $24 \mathrm{~h}$ " $(14,29)$. But a situation in which a living cell is entered and quickly killed might be considered a modification of necrotrophy, rather than biotrophy or hemibiotrophy.

Both intracellular hemibiotrophic and subcuticular intramural Colletotrichum species avoid triggering resistance responses during the symptomless phase (17). Species with an intracellular hemibiotrophic strategy require an intimate cytoplasmic interaction between the plant and the pathogen, while species with a subcuticular intramural strategy do not require such intimacy. Since the former species have a restricted host range, they are considered specialists, while the latter species are considered generalists (1). Regardless of the length of the biotrophic phase, all species eventually revert to necrotrophic development. Since $C$. acutatum is a generalist invader, only necrotrophic development was predicted, while $C$. fragariae is a specialist invader (22) for which an extended biotrophic phase was predicted to precede the necrotrophic phase. The brevity of the biotrophic phase in $C$. acutatum and $C$. fragariae leaves some uncertainty about calling these fungi hemibiotrophs and comparing their initial infection strategies in terms of previously described species.

Penetration pegs were observed in our studies at the light microscope level but not the ultrastructural level. Appressoria of C. fragariae observed at the ultrastructural level may have been in the process of forming a penetration peg or may have been arrested just prior to formation of a penetration peg. Latent or quiescent stages have been observed in fungal infections of fruits (30) where the mature appressorium often will not produce a peg until the fruit is at a particular stage of ripeness. This concept has not been sufficiently studied in strawberry for the fungal penetration of stolon, petioles, leaves, or roots. Strawberry petioles are often more resistant to infection by $C$. fragariae while the plant is in fruit $(5,8)$. Development of appressoria of some species ceases under the onset of unfavorable conditions, remains latent, and resumes when the conditions are again favorable (6). The more rapid invasion of host tissue by $C$. fragariae than by $C$. acutatum is in agreement with previous reports that $C$. fragariae is more aggressive than $C$. acutatum in inciting disease symptoms following inoculation $(24,26)$.

The distribution of chitin visualized by WGA gold probe in $C$. lindemuthianum has been reported by O'Connell and Ride (15). We found several similarities as well as some differences between their findings and our results using the same probe to study $C$. fragariae. The outer appressorial wall layer of $C$. lindemuthianum was labeled more heavily by the probe than the inner layer. By contrast, the outer appressorial wall layer of $C$. fragariae was labeled less heavily by the probe than the inner layer. The matrices of both $C$. lindemuthianum and $C$. fragariae were unlabeled. The young intracellular hyphae of $C$. lindemuthianum were unlabeled, but the invasive hyphal walls of $C$. fragariae and walls of the comparable secondary hyphae of $C$. lindemuthianum were labeled. The actively growing hyphal tips of either species labeled with less intensity than the mature walls. The outer wall layers of preinvasive structures of $C$. fragariae did not show chitin-gold complex, but the single wall layers of invasive hyphae from the earliest stages observed in planta contain chitin distribution comparable to young hyphae observed in vitro. C. fragariae did not appear to modify its chitin distribution during its very brief biotrophic phase as does $C$. lindemuthianum. This supports O'Connell and Ride's (15) suggestion that chitin masking is necessary during initial contact to establish a biotrophic relationship.

\section{ACKNOWLEDGMENTS}

We gratefully acknowledge funding for this research from the North American Strawberry Growers Association; the Mississippi Association of Plant Pathologists and Nematologists for several years of scholarship support; and S. Heinhorst for advice with the lectin probe.

\section{LITERATURE CITED}

1. Bailey, J. A., O'Connell, R. J., Pring, R. J., and Nash, C. 1992. Infection strategies of Colletotrichum species. Pages 88-120 in: Colletotrichum: Biology, Pathology and Control. J. A. Bailey and M. J. Jeger, eds. CAB International, Wallingford, U.K.

2. Benhamou, N. 1989. Preparation and application of lectin-gold complexes. Pages 95-143 in: Colloidal Gold: Principles, Methods, and Applications. M. A. Hayat, ed. Academic Press, San Diego, CA.

3. Boller, T. 1995. Chemoperception of microbial signals in plant cells. Annu. Rev. Plant Physiol. Plant Mol. Biol. 46:189-214.

4. Brown, G. E. 1977. Ultrastructure of penetration of ethylene-degreened Robinson tangerines by Colletotrichum gloeosporioides. Phytopathology 67:315-320.

5. De los Santos, B., de Paredes, G., and Munoz, F. R. 2002. Influence of anthracnose epiphytotic development on strawberry fruit production in Huelva (Southwestern Spain). Acta Hortic. 567:623-626.

6. Emmett, R. W., and Parbery, D. G. 1975. Appressoria. Annu. Rev. Phytopathol. 13:147-167.

7. Freeman, S., and Katan, T. 1997. Identification of Colletotrichum species responsible for anthracnose and root necrosis of strawberry in Israel. Phytopathology 87:516-521.

8. Howard, C. M., Maas, J. L., Chandler, C. K., and Albregts, E. E. 1992. Anthracnose of strawberry caused by the Colletotrichum complex in Florida. Plant Dis. 76:976-981.

9. Luttrell, E. S. 1974. Parasitism of fungi on vascular plants. Mycologia 66:1-15.

10. Maas, J. L. 1984. Anthracnose fruit rots (black spot). Pages 57-60 in: Compendium of Strawberry Diseases. 1st ed. J. L. Maas, ed. The American Phytopathological Society, St. Paul, MN.

11. O'Connell, R. J. 1987. Absence of a specialized interface between intracellular hyphae of Colletotrichum lindemuthianum and cells of Phaseolus vulgaris. New Phytol. 107:725.

12. O'Connell, R. J., Bailey, J. A., and Richmond, D. V. 1985. Cytology and physiology of infection of Phaseolus vulgaris by Colletotrichum lindemuthianum. Physiol. Mol. Plant Pathol. 27:75-98.

13. O'Connell, R. J., Bailey, J. A., Vose, I. R., and Lamb, C. J. 1986. Immunogold labelling of fungal antigens in cells of Phaseolus vulgaris infected by Colletotrichum lindemuthianum. Physiol. Plant Pathol. 28:99-105.

14. O'Connell, R. J., Perfect, S., Hughes, B., Carzaniga, R., Bailey, J., and Green, J. 2000. Dissecting the cell biology of Colletotrichum infection processes. Pages 57-77 in: Colletotrichum: Host Specificity, Pathology, and Host-Pathogen Interaction. D. Prusky, S. Freeman, and M. Dickman, eds. The American Phytopathological Society, St. Paul, MN.

15. O'Connell, R. J., and Ride, J. P. 1990. Chemical detection and ultrastructural localization of chitin in cell walls of Colletotrichum lindemuthianum. Physiol. Mol. Plant Pathol. 37:39-53.

16. Parbery, D. G. 1996. Trophism and the ecology of fungi associated with plants. Biol. Rev. 71:473-527. 
17. Perfect, S. E., Hughes, H. B., O'Connell, R. J., and Green, J. R. 1999. Colletotrichum: A model genus for studies on pathology and fungalplant interactions. Fungal Genet. Biol. 27:186-198.

18. Roby, D., Andreé, G., and Toppan, A. 1987. Chitin and oligosacchrides as elicitors of chitinase activity in melon plants. Biochem. Biophys. Res. Commun. 143:885-892.

19. Sato, T. 1967. A modified method for lead staining of thin sections. J. Electron Microsc. 16:133.

20. Schlumbaum, A., Mauch, F., Vögeli, U., and Boller, T. S. 1986. Plant chitinases are potent inhibitors of fungal growth. Nature 324:365-67.

21. Smith, B. J. 1998. Anthracnose crown rot. Pages 24-25 in: Compendium of Strawberry Diseases. 2nd ed. J. L. Maas, ed. The American Phytopathological Society, St. Paul, MN.

22. Smith, B. J. 1998. Anthracnose fruit rot (black spot). Pages 31-33 in: Compendium of Strawberry Diseases, 2nd ed. J. L. Maas, ed. The American Phytopathological Society, St. Paul, MN.

23. Smith, B. J. 1998. Anthracnose leaf spot and irregular leaf spot. Pages 46-48 in: Compendium of Strawberry Diseases. 2nd ed. J. L. Maas, ed. The American Phytopathological Society, St. Paul, MN.
24. Smith, B. J. 2002. Susceptibility of vegetative tissues of fruit and vegetable hosts to infection by various Colletotrichum species. Acta Hortic. 567:631-634.

25. Smith, B. J., and Black, L. L. 1987. Resistance of strawberry plants to Colletotrichum fragariae affected by environmental conditions. Plant Dis. 71:834-837.

26. Smith, B. J., and Black, L. L. 1990. Morphological, cultural, and pathogenic variation among Colletotrichum species isolated from strawberry. Plant Dis. 74:69-76.

27. Sutton, B. C. 1966. The appressoria of Colletotrichum graminicola and Colletotrichum falcatum. Can. J. Bot. 44:887-897.

28. Walker, J. C. 1921. Onion smudge. J. Agric. Res. 20:685-721.

29. Wharton, P. S., Julian, A. M., and O'Connell, R. J. 2001. Ultrastructure of the infection of Sorghum bicolor by Colletotrichum sublineolum. Phytopathology 91:149-158.

30. Whiteside, J. O. 1998. Symptomless and quiescent infections by fungi. Page 30 in: Compendium of Citrus Diseases. 1st ed. J. O. Whiteside, S. M. Garnsey, and L. W. Timmers, eds. The American Phytopathological Society, St. Paul, MN. 